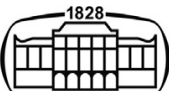

AKADÉMIAI KIADÓ

Journal of Behavioral

Addictions

9 (2020) 3, 744-755

DOl:

$10.1556 / 2006.2020 .00042$

(c) 2020 The Author(s)

\section{FULL-LENGTH REPORT}

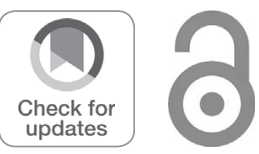

\title{
Gamblers' attitudes towards money and their relationship to gambling disorder among young men
}

\author{
PAWEL SLECZKA ${ }^{1 * \dagger}$, BARBARA BRAUN-MICHL ${ }^{2 \dagger}$ and \\ LUDWIG KRAUS ${ }^{2,3,4}$
}

\author{
${ }^{1}$ German University of Health and Sport, Ismaning, Germany \\ ${ }^{2}$ IFT Institut für Therapieforschung, Munich, Germany \\ ${ }^{3}$ Department of Public Health Sciences, Centre for Social Research on Alcohol and Drugs, Stockholm \\ University, Stockholm, Sweden \\ ${ }^{4}$ Institute of Psychology, ELTE Eötvös Loránd University, Budapest, Hungary
}

Received: March 16, 2020 • Revised manuscript received: June 4, 2020 • Accepted: June 13, 2020

Published online: July 20, 2020

\begin{abstract}
Background and aims: Money plays a central role in gambling, and understanding the different attitudes of gamblers towards it might benefit both prevention and treatment of gambling-related problems. This study describes the development of a new German measure of attitudes to money and the differences in these attitudes between male non-gamblers, occasional, frequent and problem gamblers. Furthermore, it investigates the cross-sectional and longitudinal associations between attitudes towards money and the severity of gambling disorder. Methods: An online study was conducted among 2,584 men aged 18-25 years, recruited via the Munich citizen registry. Additionally, a sample of $n=105$ Facebook users was included in part of the analyses. Frequent and problem gamblers were invited to a 12-month follow-up. Apart from gambling participation and related problems, the questionnaire included items from existing scales measuring attitudes to money. Results: Three factors underlying a new 12-item German Scale of Money Attitudes (SMAG) were identified: success, budgeting and evil. Compared with other groups, participants reporting any gambling problems scored highest in success and lowest in budgeting. Budgeting was associated with gambling-related problems in both cross-sectional and longitudinal analyses and strengthened the relationship between associating money with success and gambling disorder. Discussion: For problem gamblers, money is important as a personal symbol of success. This attitude has an especially negative effect on gambling-related problems in individuals who handle money irresponsibly. Spending and winning money might play an important role in maintaining selfesteem among gamblers and thus hinder their attempts to quit.
\end{abstract}

\section{BACKGROUND}

The role of money goes beyond the sole means of payment. It also fulfils our psychological needs of power, security, love or freedom and often plays a central role in our lives (Goldberg \& Lewis, 1978). In gambling, money has a distinctive function, as the goal of gambling is to redistribute money based on more-or-less random chances (Bühringer, Braun, Kräplin, Neumann, \& Sleczka, 2013). Unrath (2007) concluded that, for gamblers, apart from the financial wins, money can have various other meanings. It can facilitate social relations, act as a sign of social status and power, give the feeling of control and superiority, stimulate and soothe. Among problem gamblers, the topic of money might also be a source of anxiety because of their frequent financial debts (Braun, Ludwig, Kraus, Kroher, \& Bühringer, 2013). Furthermore, some of the diagnostic criteria for gambling disorder are also related to money, i.e. excessive spending on bets, financial debts or chasing; the latter is sometimes described as the driving force behind gambling-related problems (Petry, 2003). 
Vaughan and Hogg (2005) define attitudes as a stable organisation of beliefs, feelings and behavioural tendencies towards an object, groups of people, events or symbols with social significance. Several dimensions underlying attitudes to money have previously been described in relation to sex, age, education, income, life satisfaction or work motivation (for an overview, see Mitchell \& Mickel, 1999; Taneja, 2012). One of the dimensions of these attitudes is the belief that money should be saved and managed in a generally restrictive and thoughtful manner. It seems reasonable to assume that responsible budgeting is negatively associated with gambling and related problems. However, the two previous empirical studies conducted in this field failed to clearly verify this assumption. Blaszczynski and Nower (2010) identified no group differences in financial planning between 127 gamblers with different degrees of gamblingrelated problems. Lostutter and colleagues (2019) investigated a much larger sample of 2,534 students and concluded that responsible money management appears not to prevent high gambling involvement or related problems. However, both studies had some limitations, which could potentially account for the lack of significant associations. The former was based on a small sample size (Blaszczynski \& Nower, 2010), and the latter sample included only students (Lostutter et al., 2019).

Another aspect of attitudes to money is the personal value of money and its cognitive associations with success, power and prestige. This dimension is defined as associating money with better social influence and status, with social comparisons of wealth and seeing being rich as a personal life goal (Tang, 1992; Yamauchi \& Templer, 1982). People who see money as a sign of success are more prone to shop compulsively to raise their self-esteem (Hanley \& Wilhelm, 1992; Khare, 2016). Similarly, gambling has also previously been described as a way to maintain self-esteem for some gamblers (i.e. poker and sport bets players; Fang \& Mowen, 2009). Gambling is also frequently advertised as an easy way to earn money and, at the same time, a luxurious activity typical of the rich and famous (Monaghan, Derevensky, \& Sklar, 2008). It can be hypothesised that there is a link between seeing money as a symbol of success and gambling. In line with this assumption, Blaszczynski and Nower (2010) found that problem gamblers see money as a sign of success more often than non-problem gamblers. Lostutter et al. (2019) reported a relationship between perceiving money as a symbol of success and gambling expenditures and gambling-related problems. Moreover, the different dimensions of money attitudes are inter-related. Therefore, apart from the direct influence of money attitudes on gambling, it is also possible that the personal importance of money as a sign of success might be even more problematic among people with poor budgeting: they might be especially prone to develop gambling-related problems.

At present, a German instrument measuring money attitudes is not available, and the English questionnaires generally lack sufficient validation. There is no consensus on the number and content of factors to be measured (Lay \& Furnham, 2019; Tang, Furnham, \& Davis, 2002), and the frequently used instruments such as the Money Belief and Behavior Scale (MBBS: Furnham, 1984) or Money Attitude Scale (MAS: Yamauchi \& Templer, 1982) had different factor structures when tested in other cultures (Roberts \& Sepulveda, 1999; Tatarko \& Schmidt, 2012). Therefore, instead of adapting any of the available instruments, it seems more productive to use multiple existing scales to derive a new instrument.

\section{Study aims}

The current study aims to (1) develop and evaluate a German scale of money attitudes. By addressing the limitations of the two previous studies, it (2) investigates money attitudes among a large sample of male non-gamblers, occasional, frequent gamblers and participants reporting any gambling problems. Moreover, (3) it analyses the crosssectional and longitudinal relations between money attitudes and the severity of gambling disorder and (4) tests the hypothesis of a moderating effect of budgeting on the relation between viewing money as a sign of success and the severity of gambling disorder.

\section{METHODS}

\section{Study design and procedure}

The current study was part of the Munich Leisure-time Study (MLS), a longitudinal online study of factors associated with gambling-related problems among young men. The study design was based on a large-scale, cross-sectional baseline survey and a 12-month follow-up with a smaller sample of frequent gamblers and participants reporting gambling problems. For further details on the study design, see Sleczka, Braun, Grüne, Bühringer, and Kraus (2016, 2018).

\section{Participants}

In 2014, 25,000 men aged 18-25 years, randomly chosen from the population registry of Munich, Bavaria (Einwohnermeldeamtsregister), were invited to join the study. The registry includes the addresses of all city inhabitants, who are obligated by law to notify the city council within two weeks after changing their permanent addresses. Restricting the recruitment only to young men was determined by the primary goals of the MLS. A total number of $n=2,588$ (response rate $=10.3 \%$ ) participants fulfilled the baseline MLS questionnaire. From these, $\mathrm{n}=4$ questionnaires were excluded because of unreliable answers. In the baseline study, the participants were 22.3 ( $\mathrm{SD}=2.29$ ) years old, $58.5 \%$ were students, and $43.9 \%$ were in a relationship.

Part of the analyses was conducted on longitudinal data from the 12-month follow-up. In addition to participants recruited from the baseline study, a sample of $n=102$ Facebook users, targeted based on their gambling interests, was recruited in order to increase the sample size. All participants who gambled frequently (at least once a week) and/ 
or reported any signs of problem gambling ( $\geq 1$ symptom according to DSM-5 or $\geq 1$ point in the Lie-Bet questionnaire: American Psychiatric Association, 2013; Johnson, Hamer, \& Nora, 1998) were invited to join the follow-up study. The follow-up sample consisted of $n=122$ participants: $n=73$ from the cross-sectional study and $n=49$ Facebook users. Participants in the longitudinal part of the study received shopping coupons $(€ 15)$ as incentives.

\section{MEASURES}

\section{Development of the German measure of money attitudes}

The first aim of the study was to create a new short measure of money attitudes based on previous instruments. The search for instruments provided several options, which have nonetheless not been fully evaluated and were rarely applied in research in clinical populations: MBBS (Furnham, 1984), MAS (Yamauchi \& Templer, 1982), the long and short versions of the Money Ethic Scale (MES: Tang, 1992, 1995) and the Money Importance Scale (MIS: Mitchell \& Mickel, 1999).

All scales were translated into German by two translators with psychology backgrounds and back-translated by an assistant unaware of the original items. Differences in translation were discussed and revised; some idioms and formulations were replaced by their German equivalents and, in a few cases, items were excluded when no German equivalent could be found. Based on the translated scales, a base set of $n=38$ items was created (see Appendix 1). This set included the complete long version of the MES, which was the most widely validated instrument at that time. It also included items related to constructs not measured by the MES and one new item 'money has to be earned through hard work'. To ensure divergent validity (difference from financial consequences of gambling), no items related to gambling were included.

The baseline study included the full set of items and the follow-up only its shortened final version (described under Results). Participants responded by moving the mouse cursor on a visual analogue scale with the extremes labelled $1=$ 'not at all' and $10=$ 'completely'.

\section{Gambling participation and gambling-related problems}

Gambling participation was defined as participating in any kind of 19 different types of gambling available in Germany. These included sport bets, slot machines, online gambling, roulette, lotteries, bingo, card games, gambling with family etc. The possible answers were $1=$ never, $2=$ more than 12 months ago, $3=$ within the last 12 months but less than weekly and $4=$ more than once a week in the last 12 months.

The 12-month prevalence of symptoms of gambling disorder were measured using the questionnaire from Stinchfield (2003), adapted to DSM-5 by excluding two items related to the DSM-IV criterion of illegal activities. All but the withdrawal symptom (one item) were assessed with two items on a dichotomous (yes/no) answer scale. The German adaptation of the questionnaire was previously applied in several epidemiological studies (Bühringer, Kraus, Sonntag, Pfeiffer-Gerschel, \& Steiner, 2007; Sassen et al., 2011) showing a high internal consistency of $\alpha=0.91$.

\section{Statistical analyses}

An Exploratory Factor Analysis (EFA) with orthogonal rotation (varimax) was conducted on the base set of items. Based on the EFA results, a factor structure was chosen. The set of items was then shortened through exclusion of items with low factor loading, with a redundant content compared with other items in the assigned factor or with an unclear relation to the assumed factor. The final factor structure was evaluated in a Confirmatory Factor Analysis (CFA) using the maximum likelihood method. The factor loadings and residual variances were unrestrained, and the standard errors were estimated based on the observed information matrix (OIM). The baseline sample was randomly split in half for the EFA and the CFA. Consequently, the analyses were conducted on independent samples, each containing $n$ $=1,292$ participants.

ANOVAs were conducted to compare the values of the identified scales in groups with (a) no gambling (never gambled or not in the last 12 months), (b) past year occasional gambling (less than weekly), (c) frequent gambling (more than once a week) and (d) any gambling problems ( $\geq$ 1 symptom according to DSM-5, regardless of gambling frequency). Regression analyses were conducted to investigate cross-sectional and longitudinal associations between money attitudes and severity of gambling disorder. The outcome variables in the models were the log-transformed number of fulfilled symptoms at baseline (Model 1) and follow-up (Model 2). The logarithm of the number of symptoms was taken to adjust the data to the assumption of normally distributed standard errors. In both models, the baseline scores in money attitudes were included as predictors. Non-gamblers were excluded from the analyses as they could not fulfil any criteria. This resulted in a sample of $n=1,247$ participants in Model 1; Model 2 was conducted with data from $n=122$ participants in the follow-up study. The moderation effects were investigated using the PROCESS extension (Hayes, 2017) in SPSS. The outcome variable in the regression model was the log-transformed number of fulfilled criteria at baseline, the perception of money as a symbol of success was the main predictor, and budgeting was included as a moderator. Heteroscedasticityconsistent standard errors were applied. The analyses were conducted on the data from $n=1,247$ occasional baseline gamblers. The moderation analysis based on longitudinal data was not possible because of the small size of the followup sample. The CFA was conducted in STATA 12 SE (StataCorp LP, 2011). All other analyses were conducted in SPSS (IBM Corp., 2017). 
Table 1. Factor loadings and item characteristics for the final scale $(n=2,588)$.

\begin{tabular}{|c|c|c|c|c|c|c|c|c|c|c|c|c|}
\hline \multirow[b]{2}{*}{ No. } & \multirow[b]{2}{*}{ Scale/item } & \multicolumn{8}{|c|}{ Item $_{\text {characteristics }}{ }^{1}$} & \multicolumn{3}{|c|}{ Factor loadings $^{2}$} \\
\hline & & Miss. & $M$ & SD & Diff. & $r_{\mathrm{it}-1}$ & $r_{\mathrm{it}-2}$ & $r_{\text {it }-3}$ & $\alpha$ & 1 & 2 & 3 \\
\hline & Success $(M=4.97, S D=1.81)$ & 72 & & & & & & & & & & \\
\hline 12 & $\begin{array}{l}\text { Money can give you the opportunity to } \\
\text { be what you want to be. }\end{array}$ & 74 & 4.94 & 2.55 & .44 & .49 & & & & .55 & -.05 & .00 \\
\hline 10 & Money is a symbol of success. & 58 & 5.51 & 2.49 & .50 & .62 & & & & .69 & .02 & -.05 \\
\hline 11 & $\begin{array}{l}\text { Money is the most important thing } \\
\text { (goal) in my life. }\end{array}$ & 146 & 3.53 & 2.35 & .28 & .63 & & & & .72 & -.02 & .02 \\
\hline 2 & I value money very high. & 105 & 5.87 & 2.30 & .54 & .61 & & & & .70 & .04 & -.20 \\
\hline \multirow[t]{2}{*}{8} & $\begin{array}{l}\text { I believe the more money you have, } \\
\text { the happier you are. }\end{array}$ & 78 & 4.07 & 2.50 & .34 & .66 & & & .81 & .74 & -.06 & .01 \\
\hline & Budget $(M=7.32, S D=1.70)$ & 91 & & & & & & & & & & \\
\hline 6 & I use my money very carefully. & 24 & 6.74 & 2.25 & .64 & & .66 & & & .05 & .78 & .06 \\
\hline 9 & I budget my money very well. & 65 & 6.89 & 2.26 & .65 & & .71 & & & .05 & .85 & -.01 \\
\hline 1 & $\begin{array}{l}\text { I know almost to the penny how much } \\
\text { money I have. }\end{array}$ & 33 & 8.08 & 2.12 & .79 & & .40 & & & .09 & .45 & -.07 \\
\hline 4 & $\begin{array}{l}\text { I show some worrisome behaviour } \\
\text { when it comes to money. }\end{array}$ & 126 & 7.51 & 2.41 & .72 & & .56 & & & -.16 & .62 & -.12 \\
\hline \multirow[t]{2}{*}{5} & $\begin{array}{l}\text { If I have money left over at the end of } \\
\text { the month (week) I often feel } \\
\text { uncomfortable until it is all spent. }\end{array}$ & 158 & 8.11 & 2.13 & .79 & & .54 & & .80 & -.16 & .60 & -.10 \\
\hline & Evil $(M=4.37, S D=2.19)$ & 72 & & & & & & & & & & \\
\hline 3 & Money is the root of all evil. & 74 & 4.93 & 2.72 & .44 & & & $.46^{4}$ & & -.05 & -.04 & .62 \\
\hline 7 & Money is shameful. ${ }^{3}$ & 58 & 3.71 & 2.39 & .30 & & & $.46^{4}$ & .63 & -.07 & -.12 & .73 \\
\hline
\end{tabular}

Note: Miss. - missing values, $M$ - mean, $S D$ - standard deviation, Diff. - item difficulty, $r_{i t}$ - item-total correlation, $\alpha$ - Cronbach's alpha; ${ }^{1}$ pairwise deletion when missing values; ${ }^{2}$ listwise deletion when missing values; ${ }^{3}$ slightly different wording in German; ${ }^{4}$ correlation between the two items.

\section{Ethics}

The study was approved by the Ethical Board of the German Psychological Society (LK-102013). All participants were informed about the study and provided informed consent.

\section{RESULTS}

\section{Psychometric analysis}

The EFA indicated a good sample fit with an overall $\mathrm{KMO}=$ 0.88 (e.g. Field, 2009), the sphericity test $\chi^{2}(703)=$ $12,787.10, p<0.001$, R-matrix determinant of $>0.00001$ and $11(1.0 \%)$ non-redundant residuals $(<0.05)$ between the observed and reproduced correlations. Nine factors had an eigenvalue of $>1$ (Kaiser criterion). However, based on the scree plot analysis (Appendix 2) and strong similarities to the previously identified factor solution in MES, a threefactor solution was chosen. The excluded factors were either strongly under-determined with no or only one item exceeding factor loading of 0.3 , included heterogeneous items, or were very similar to the obtained factors. The three factors explained $34.7 \%$ of the variance of all answers and reflected the perception of money as a symbol of success, budgeting and seeing money as evil. The factor loadings are presented in Appendix 1. In a second step, all items with low factor loadings, with redundant content within the assumed factor or with an unclear relation to the assumed factor were eliminated, resulting in a questionnaire with 12 items. An additional EFA on the 12 items showed the same three factors explaining $59.7 \%$ of the variance of all answers. All factor loadings were higher than 0.45 (see Table 1).

The results of the CFA are illustrated in Figure 1. The fit statistics were $\chi^{2}(51)=259.24, p<0.001, \mathrm{CFI}=0.94$, SRMR $=0.05$, RMSEA $=0.06$, RMSEA 90\% CI $=0.06-$ 0.07 . Although most of the fit statistics indicated a good model fit, the CFI was lower than 0.95 , suggesting a suboptimal data fit ${ }^{1}$.

Owing to similarities between the new measure and the MES (Tang, 1995), the scales were labelled as success, budgeting and evil. The item and scale characteristics as well as the factor loadings of the scale are shown in Table 1. Cronbach's alphas were $\alpha=0.81$ for success, $\alpha=0.80$ for budgeting and $\alpha=0.63$ for evil. The usefulness of Cronbach's alpha in assessing the reliability of very short scales is limited because of its dependence on the number of items (Cortina, 1993). Therefore, the inter-correlation coefficient between items was used. The obtained correlation value of $r$ $=0.46$ can be interpreted as acceptable (Clark \& Watson, 1995).

\footnotetext{
${ }^{1}$ Adding two additional covariance relations between item 4 and items 11 and 12 , which was suggested in modification indices and is coherent with the content of the items, improved the model $\left(\chi^{2}(49)=198.65, p<0.001\right.$, $\mathrm{CFI}=0.96, \mathrm{SRMR}=0.05$, RMSEA $=0.05$, RMSEA 90\% CI $=0.05-0.06$ ).
} 


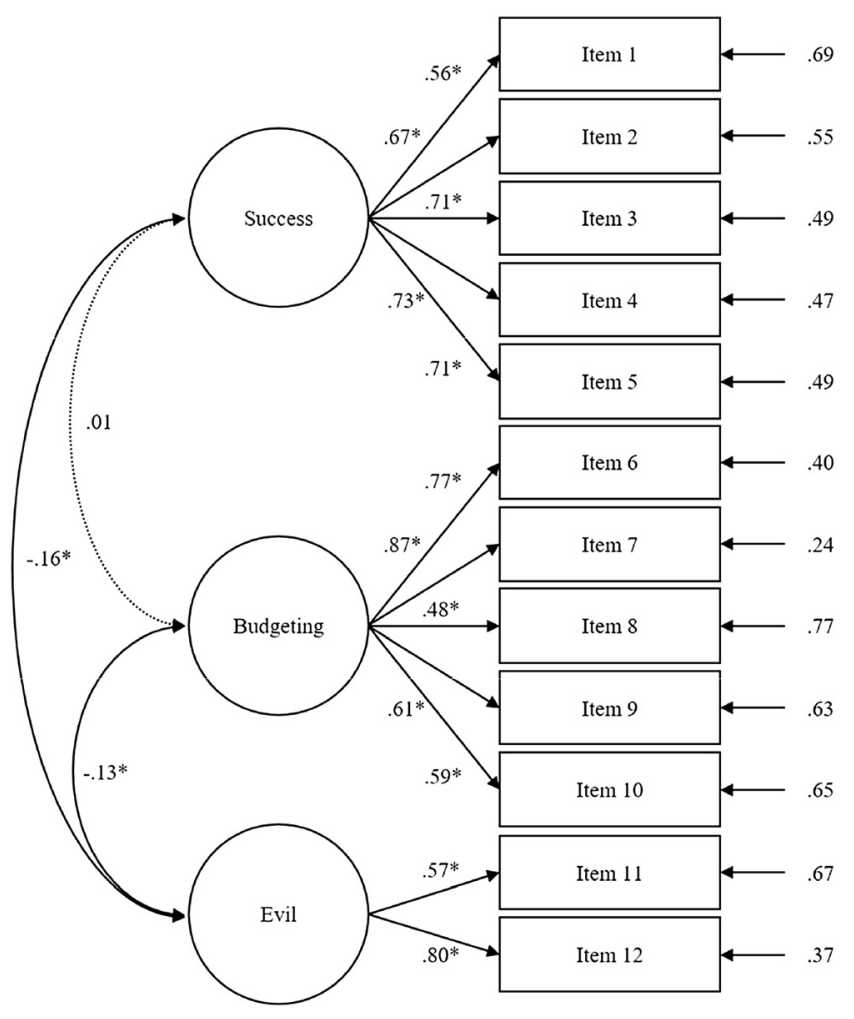

Figure 1. Factor structure of the German measure of money attitudes; ${ }^{*}$ significant at $p<0.05$.

The scales correlated with each other at a low level. Success correlated with budgeting at $r=-0.04, p<0.05$, and with evil at $r=-0.10, p<0.001$. The correlation between evil and budgeting was $r=-0.12, p<0.001$. In order to estimate the stability of the three factors, the scale scores at baseline were correlated with the scores at follow-up. The stability rates were $r_{t t}=0.64, p<0.001$ for success, $r_{t t}=0.72$, $p<0.001$ for budgeting and $r_{t t}=0.65, p<0.001$ for evil.

\section{Money attitudes and gambling}

In total $n=1,337$ participants were classified as non-gamblers, $n=1,033$ as occasional gamblers, $n=84$ as frequent gamblers (without gambling problems) and $n=130$ gamblers fulfilled at least one DSM-5 criterion for gambling disorder (among the latter $n=24$ did not gamble frequently). The latter group included $n=30$ pathologic gamblers (4+ DSM-5 criteria; $n=2$ did not gamble frequently). The ANOVA revealed statistically significant differences between the four compared groups in two scales: success $(F(3,2,579)=15.67, p<0.001)$ and budgeting $(F(3$, $2,579)=10.40, p<0.001)$. The scores on evil did not differ between the groups $(F(3,2,538)=0.71, p>0.05)$. The results of the post hoc tests are illustrated in Figure 2.

The results of the regression models are displayed in Table 2. As hypothesised, success was positively, but budgeting negatively associated with the severity of gambling disorder in cross-sectional analyses. Evil (no specific hypothesis) was also a statistically significant predictor of gambling-related problems. Only budgeting predicted the severity of gambling disorder after 12 months.

Table 3 contains the results of the moderation analysis with budgeting moderating the effects of success on the severity of gambling disorder. The significant interaction coefficient and the analysis of the conditional effects (illustrated in Figure 3) support the hypothesis that poor budgeting strengthens the impact of success on the severity of gambling disorder. At higher values of budgeting, the effect of success on gambling-related problems was not statistically significant. Owing to the inclusion of the interaction effect, the effects of predictors and $\beta$-values (not reported) cannot be interpreted in the usual manner (Hayes, 2017).

\section{DISCUSSION}

Based on the present analyses, a new German instrument is proposed, measuring three dimensions of money attitudes: viewing money as a sign of success, of evil and responsible budgeting. The instrument was applied to investigate differences in money attitudes in non-gamblers, occasional, frequent and gamblers reporting any problems (regardless of gambling frequency). The study also estimated the crosssectional and longitudinal associations between the three scales and the severity of gambling disorder and analysed the moderating effect of budgeting on the association between perceptions of money as a sign of success and gambling disorder.

The identified factor structure is very similar to that of the Money Ethic Scale (Tang, 1992), which is the reason why the original scale names were applied. The similarities are remarkable given that the initial set of items included items from several scales and only five items in the final version are items from the MES. Despite small differences in item wording as a result of language and cultural differences, our results support the validity of the short MES. The scale evil reflects the negative evaluation of money as a possible reason for immoral behaviour. The other two scales measure the personal importance of money and its cognitive inclinations

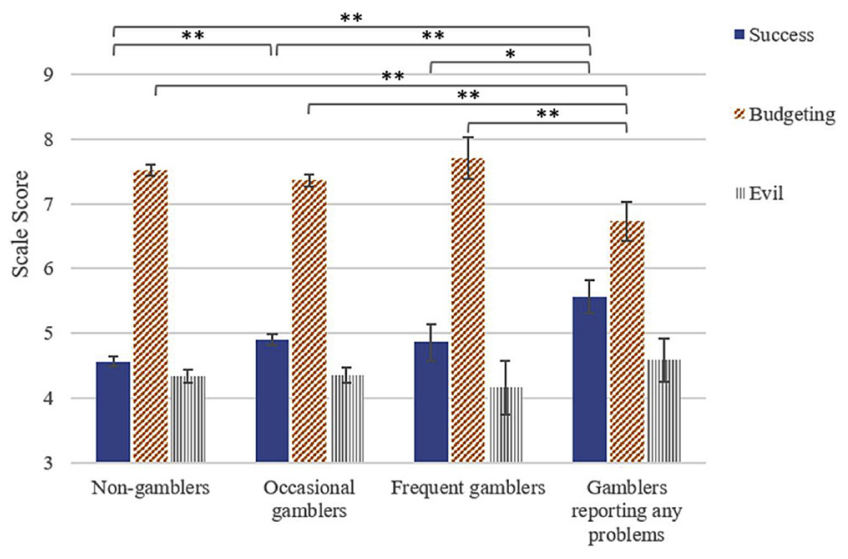

Figure 2. Money attitudes (with $95 \%$ confidence intervals) among the compared groups; ${ }^{\star} p<0.05,{ }^{\star *} p<0.001$. 
Table 2. Regression analysis with money attitudes as predictors of the severity of gambling disorder.

\begin{tabular}{|c|c|c|c|c|c|c|}
\hline & \multicolumn{3}{|c|}{$\begin{array}{l}\text { Severity of gambling disorder }{ }^{1} \text { at baseline } \\
\qquad(n=1,247)\end{array}$} & \multicolumn{3}{|c|}{$\begin{array}{l}\text { Severity of gambling disorder }{ }^{1} \text { at } 12 \text {-month } \\
\text { follow-up }(n=122)\end{array}$} \\
\hline & B & SE B & B & B & SE B & $\beta$ \\
\hline Constant & 0.081 & 0.028 & & 1.690 & 0.436 & \\
\hline Success & $0.009^{\star *}$ & 0.003 & $.101^{\star *}$ & 0.013 & 0.042 & .027 \\
\hline Budget & $-0.013^{\star *}$ & 0.003 & $-.133^{\star *}$ & $-0.152^{\star *}$ & 0.037 & $-.363^{\star x}$ \\
\hline Evil & $0.005^{\star}$ & 0.002 & $.060^{*}$ & 0.016 & 0.034 & .041 \\
\hline
\end{tabular}

Note: $R^{2}=0.04$ in Model 1 and $R^{2}=0.14$ in Model 2. ${ }^{\star} p<0.05,{ }^{\star *} p<0.001$; ${ }^{1} \log$-transformed number of the fulfilled DSM-5 criteria for the gambling disorder.

to success and the behavioural tendencies in spending money, ranging from impulsive expenditures to responsible budgeting and savings. These two constructs fit the broader definition of attitudes (Vaughan \& Hogg, 2005) and not the conservative definition, which restricts attitudes to evaluations of attitudes' object (Albarracin \& Shavitt, 2018). The internal consistency of the three scales can be evaluated as only just acceptable (evil) to good, and the correlations between baseline and 12-month follow-up values speak for good retest reliability and high stability of money attitudes (Stemmler, Hagemann, Amelang, \& Spinath, 2016). Altogether, the presented German Scale of Money Attitudes (SMAG) can be recommended for further research, but requires further research on samples representative of women and other age groups before being applied for individual diagnosis.

The ANOVAs revealed that participants reporting any gambling problems had higher scores on success than nongamblers, occasional and frequent gamblers. The scale resembles the personal value of money ("Money is the most important goal in my life') and its association with social

Table 3. Moderation analysis with budget scale as the moderator of the relation between the success scale and the severity of gambling disorder.

\begin{tabular}{lcc}
\hline & \multicolumn{2}{c}{$\begin{array}{c}\text { Severity of gambling } \\
\operatorname{disorder}^{1}(n=1,247)\end{array}$} \\
\cline { 2 - 3 } & $\mathrm{B}$ & SE B \\
\hline Constant & -0.059 & 0.028 \\
Success & 0.010 & 0.017 \\
Budget & $-0.080^{*}$ & 0.003 \\
Interaction: Success $\times$ Budget & $0.005^{*}$ & 0.002 \\
\hline Conditional effects for different values of the moderator $($ budget $)$ \\
\hline & Severity of gambling \\
& disorder ${ }^{1}(n=1,247)$ \\
\cline { 2 - 3 } Conditional effects & B & SE B \\
\hline Success (Budget $=5.622)$ & $-0.015^{*}$ & 0.003 \\
Success (Budget $=7.320)$ & $-0.009^{*}$ & 0.002 \\
Success (Budget $=9.018)$ & -0.003 & 0.003 \\
\hline
\end{tabular}

Note: $\mathrm{R} 2=0.04 .{ }^{*} \mathrm{p}<0.001 ;{ }^{1} \log$-transformed number of the fulfilled. DSM- 5 criteria for gambling disorder at baseline; $\beta$ values are not interpreted within moderation analysis. prestige and success ('Money is a symbol of success') and was also related to the severity of gambling-related problems in the cross-sectional analyses. Although significant, the associations were generally low, which might be attributed to the rather general assessment of money attitudes, not specific to gambling. These results are in line with reports from Blaszczynski and Nower (2010) and Lostutter et al. (2019), where seeing money as a symbol of success raised the chances of more intensive gambling involvement and more related problems. Gambling is advertised as a way to get rich quickly and effortlessly; gamblers in advertisements are rich and successful and are often portrayed by celebrities (Monaghan, Derevensky, \& Sklar, 2008). It is possible that individuals viewing money as a promise of success, power, freedom and social prestige might see gambling as a way to fulfil their ambitions. Apart from dreams of becoming rich, gambling can also play an important role in raising and maintaining self-esteem. In fact, Fang and Mowen (2009) showed that some gamblers use gambling to boost their selfesteem, and Blaszczynski and Nower (2010) proposed that the symbolical value of gambling wins as personal success might be more important than their monetary value. Similarly, gambling expenditures can also be viewed as 'proof of disposable income and wealth. Thus, in analogy with shopping expenditures among compulsive buyers (Hanley \& Wilhelm, 1992; Khare, 2016; Roberts \& Jones, 2001),

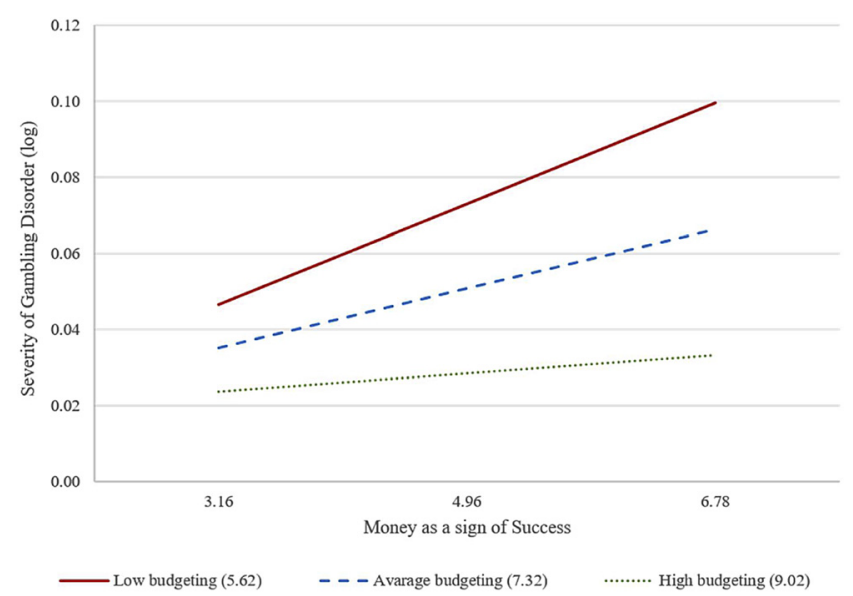

Figure 3. The moderating effect of budgeting on the relation between success and the severity of gambling disorder. 
gambling expenditures could be a means of demonstrating status and power.

In our study, participants reporting any gambling problems differed in their attitude towards money budgeting from the three other compared groups, which gambled less or gambled without experiencing problems. A responsible attitude towards handling money was also a negative predictor of the severity of gambling disorder in both crosssectional and longitudinal analyses. The two previous studies in this field hypothesised these relations, but were unable to find them, which might have been a result of small sample size (Blaszczynski \& Nower, 2010) or a sample of students, for whom budgeting might play a less significant role (Lostutter et al., 2019). The current study addressed these limitations by investigating a large randomly selected sample of young men. The investigated associations could presumably have been stronger had the study sample also included older participants. The results obtained suggest that responsible budgeting might not differ between non-gamblers, recreational and frequent gamblers, but rather between individuals with and without gambling-related problems. Irresponsible money management can be a result of impulsiveness, which has often been described as a risk factor for gambling-related problems (Lorains, Cowlishaw, \& Thomas, 2011; MacLaren, Fugelsang, Harrigan, \& Dixon, 2011). The potential mediating role of budgeting in the relationship between impulsiveness and gambling-related problems should therefore be addressed in further studies. However, it cannot be ruled out that expressing difficulties with personal budgeting might actually reflect problem insights into the gambling disorder. Finally, the conducted moderation analysis supported the hypothesis that irresponsible budgeting strengthens the effect of viewing money as a sign of success and gamblingrelated problems. Individuals who see money as a sign of personal success and, at the same time, have difficulties managing their budget have an even higher risk of gambling-related problems.

The current study has some limitations that need to be considered when generalising the results. First, our results are generalizable to young men only. However, in their analysis, Lostutter and colleagues (2019) demonstrated that the major effects of money attitudes are independent of sex. Second, a large part of the analysis is based on crosssectional design, which does not allow any causal conclusions, and the presented explanations thus reflect hypotheses rather than causal statements. We assumed that specific money attitudes can lead to gambling-related problems, but it is also possible that these attitudes change in the course of the development of such problems. Third, although individuals were randomly selected in the registry sample, both samples (registry and Facebook) can be presumed to be selective because of the low response rate. Fourth, the retest reliability rates might be inflated due to the homogeneous sample consisting of frequent or problem gamblers. Fifth, the groups in the ANOVA differ qualitatively and the last group of participants reporting any problems includes both frequent and non-frequent gamblers (e.g. irregular highstake gamblers) and, at the same time, sub-clinical problems
(1-3 DSM-5 criteria) and pathological (4+ DSM-5 criteria) gamblers. As such, this group is rather heterogeneous, which partially limits the possible interpretation of the identified differences. Finally, in the cross-sectional analysis, there was a statistically significant positive association between the perception of money as evil and gambling disorder. However, this relation is complex, and the current literature does not allow clear conclusions about it. This association should therefore be considered with caution.

\section{CONCLUSION}

The current study highlights the importance of attitudes towards money in the understanding of gambling-related problems. In general, problem gamblers see money as an important factor in life, symbolic of personal success, which might be a further motivator to gamble. Moreover, irresponsible money management seems to be a risk factor for gambling-related problems and moderates the relation between the personal value of money and the severity of gambling disorder: seeing money as a personal symbol of success has an especially negative effect on gambling-related problems for individuals with irresponsible budgeting.

Spending and winning money might play an important role in the self-concept of gamblers, analogous to extensive shopping in compulsive buyers (Khare, 2016). Maintaining high self-esteem is a natural need of every individual (Petersen, Stahlberg, \& Dauenheimer, 2000); hence, ceasing gambling without any other alternative way to boost selfesteem might facilitate relapse. These results provide empirical support for the experience-based treatment recommendations of Gupta and Derevensky (2000). Discussing effective money management and addressing the role that money, gambling expenditures and gambling wins play in the self-esteem of the gambler can benefit the therapy of gambling disorder.

Funding sources: The study was conducted at the Bavarian Coordination Centre for Gambling Issues, which is funded by the State of Bavaria based on an unrestricted grant. Funding for LK was also provided by the Swedish program grant "Responding to and Reducing Gambling Problems Studies in Help-seeking, Measurement, Comorbidity and Policy Impacts" financed by the Swedish Research Council for Health, Working Life and Welfare (Forte), grant number 2016-07091.

Authors' contribution: PS, BBM and LK designed the study. PS and BBM developed the research question and interpreted the results. BBM conceptualised and developed the first version of the questionnaire. PS coordinated, prepared and conducted the study, ran the statistical analyses and wrote the first draft of the manuscript. All authors had full access to all data in the study and take responsibility for the integrity of the data and the accuracy of the data analysis. All authors contributed to and approved the final manuscript. 
Conflict of interest: The State of Bavaria provides gambling services (lotteries, sports betting and casino games) within the State gambling monopoly via the State Lottery Administration. Authors have no other personal COI.

\section{REFERENCES}

Albarracin, D., \& Shavitt, S. (2018). Attitudes and attitude change. Annual Review of Psychology, 69(4), 299-327. https://doi.org/ 10.1146/annurev-psych-122216-011911.

American Psychiatric Association. (2013). Diagnostic and statistical manual of mental disorders (DSM-5). American Psychiatric Pub.

Blaszczynski, A., \& Nower, L. (2010). Instrumental tool or drug: Relationship between attitudes to money and problem gambling. Addiction Research \& Theory, 18(6), 681-691. https://doi.org/10.3109/16066351003786752.

Braun, B., Ludwig, M., Kraus, L., Kroher, M., \& Bühringer, G. (2013). Ambulante Suchthilfe für pathologische Glücksspieler in Bayern: Passung zwischen Behandlungsbedarf und -angebot. Suchttherapie, 14(01), 37-45. https://doi.org/10.1055/s-00321323802.

Bühringer, G., Braun, B., Kräplin, A., Neumann, M., \& Sleczka, P. (2013). Gambling-two sides of the same coin: Recreational activity and public health problem. ALICE RAP Policy Paper Series-Policy Brief, vol. 2. http://www.alicerap.eu/resources/ documents/cat_view/1-alice-rap-project-documents/19-policypaper-series.html?start $=5$.

Bühringer, G., Kraus, L., Sonntag, D., Pfeiffer-Gerschel, T., \& Steiner, S. (2007). Pathologisches Glücksspiel in Deutschland: Spiel-und Bevölkerungsrisiken. Sucht, 53(5), 296-307. https:// doi.org/10.1024/2007.05.06.

Clark, L. A., \& Watson, D. (1995). Constructing validity: Basic issues in objective scale development. Psychological Assessment, 7(3), 309. https://doi.org/10.1037/1040-3590.7.3.309.

Cortina, J. M. (1993). What is coefficient alpha? An examination of theory and applications. Journal of Applied Psychology, 78(1), 98. https://doi.org/10.1037/0021-9010.78.1.98.

Fang, X., \& Mowen, J. C. (2009). Examining the trait and functional motive antecedents of four gambling activities: Slot machines, skilled card games, sports betting, and promotional games. Journal of Consumer Marketing, 26(2), 121-131. https://doi.org/ 10.1108/07363760910940483.

Field, A. (2009). Discovering statistics using SPSS, 3rd Edition. Sage Publications.

Furnham, A. (1984). Many sides of the coin: The psychology of money usage. Personality and Individual Differences, 5(5), 501509. https://doi.org/10.1016/0191-8869(84)90025-4.

Goldberg, H., \& Lewis, R. T. (1978). Money madness: The psychology of saving, spending, loving, and hating money. Wellness Institute.

Gupta, R., \& Derevensky, J. L. (2000). Adolescents with Gambling Problems: From Research to Treatment. Journal of Gambling Studies, 16(2), 315-342. https://doi.org/10.1023/A:1009493200768.

Hanley, A., \& Wilhelm, M. S. (1992). Compulsive buying: An exploration into self-esteem and money attitudes. Journal of Economic Psychology, 13(1), 5-18. https://doi.org/10.1016/ 0167-4870(92)90049-D.
Hayes, A. F. (2017). Introduction to mediation, moderation, and conditional process analysis: A regression-based approach, 2 nd ed., Guilford Publications.

IBM Corp. (2017). IBM SPSS statistics for windows (25.0.) [Computer software]. IBM Corp.

Johnson, E. E., Hamer, R. M., \& Nora, R. M. (1998). The Lie/Bet Questionnaire for screening pathological gamblers: A follow-up study. Psychological Reports, 83(3), 1219-1224. https://doi.org/ 10.2466/pr0.1998.83.3f.1219.

Khare, A. (2016). Money attitudes, credit card and compulsive buying behaviour: A study on Indian consumers. International Journal of Business Competition and Growth, 5(1), 49. https:// doi.org/10.1504/IJBCG.2016.079935.

Lay, A., \& Furnham, A. (2019). A new money attitudes questionnaire. European Journal of Psychological Assessment, 35(6), 813-822. https://doi.org/10.1027/1015-5759/a000474.

Lorains, F. K., Cowlishaw, S., \& Thomas, S. A. (2011). Prevalence of comorbid disorders in problem and pathological gambling: Systematic review and meta-analysis of population surveys. Addiction, 106(3), 490-498. https://doi.org/10.1111/j.13600443.2010.03300.x.

Lostutter, T. W., Enkema, M., Schwebel, F., Cronce, J. M., Garberson, L. A., Ou, B., (2019). Doing it for the money: The relationship between gambling and money attitudes among college students. Journal of Gambling Studies, 35(1), 143-153. https://doi.org/10.1007/s10899-018-9789-4.

MacLaren, V. V., Fugelsang, J. A., Harrigan, K. A., \& Dixon, M. J. (2011). The personality of pathological gamblers: A metaanalysis. Clinical Psychology Review, 31(6), 1057-1067. https:// doi.org/10.1016/j.cpr.2011.02.002.

Mitchell, T. R., \& Mickel, A. E. (1999). The meaning of money: An individual-difference perspective. Academy of Management Review, 24(3), 568-578. https://doi.org/10.5465/amr.1999.2202138.

Monaghan, S., Derevensky, J., \& Sklar, A. (2008). Impact of gambling advertisements and marketing on children and adolescents: Policy recommendations to minimise harm. Journal of Gambling Issues, 1(22), 252. https://doi.org/10.4309/jgi.2008.22.7.

Petersen, L. E., Stahlberg, D., \& Dauenheimer, D. (2000). Selbstkonsistenz und Selbstwerterhöhung: Der Integrative Selbstschemaansatz. In W. Greve (Ed.), Psychologie des Selbst (pp. 239-254). Psychologie Verlags Union.

Petry, J. (2003). Glücksspielsucht: Entstehung, Diagnostik und Behandlung. Hogrefe Verlag.

Roberts, J. A., \& Jones, E. (2001). Money attitudes, credit card use, and compulsive buying among American college students. Journal of Consumer Affairs, 35(2), 213-240.

Roberts, J. A., \& Sepulveda, C. J. (1999). Demographics and money attitudes: A test of Yamauchi and Templers (1982) money attitude scale in Mexico. Personality and Individual Differences, 27(1), 19-35. https://doi.org/10.1016/S0191-8869(98)00241-4.

Sassen, M., Kraus, L., Bühringer, G., Pabst, A., Piontek, D., \& Taqi, Z. (2011). Gambling among adults in Germany: Prevalence, disorder and risk factors. Sucht, 57(4), 249-257. https://doi.org/ 10.1024/0939-5911.a000115.

Sleczka, P., Braun, B., Grüne, B., Bühringer, G., \& Kraus, L. (2016). Proactive coping and gambling disorder among young men. Journal of Behavioral Addictions, 5(4), 639-648. https://doi.org/ 10.1556/2006.5.2016.080. 
Sleczka, P., Braun, B., Grüne, B., Bühringer, G., \& Kraus, L. (2018). Family functioning and gambling problems in young adulthood: The role of the concordance of values. Addiction Research \& Theory, 26(6), 447-456. https://doi.org/10.1080/16066359.2017.1393531.

StataCorp LP. (2011). Stata user's guide. Release 12. Stata Press Publication.

Stemmler, G., Hagemann, D., Amelang, M., \& Spinath, F. (2016). Differentielle Psychologie und Persönlichkeitsforschung. Kohlhammer Verlag.

Stinchfield, R. (2003). Reliability, validity, and classification accuracy of a measure of DSM-IV diagnostic criteria for pathological gambling. American Journal of Psychiatry, 160(1), 180-182. https://doi.org/10.1176/appi.ajp.160.1.180.

Taneja, R. M. (2012). Money attitude-An abridgement. International Refereed Research Journal, 3(3), 1-5.

Tang, T. L.-P. (1992). The meaning of money revisited. Journal of Organizational Behavior, 13(2), 197-202. https://doi.org/10. 1002/job.4030130209.

Tang, T. L.-P. (1995). The development of a short money ethic scale: Attitudes toward money and pay satisfaction revisited.
Personality and Individual Differences, 19(6), 809-816. https:// doi.org/10.1016/S0191-8869(95)00133-6.

Tang, T. L.-P., Furnham, A., \& Davis, G. M.-T. W. (2002). The meaning of money: The money ethic endorsement and workrelated attitudes. Journal of Managerial Psychology, 547-563. https://doi.org/10.1108/02683940210444021.

Tatarko, A., \& Schmidt, P. (2012). Social capital and attitudes towards money (No. WP BRP/07/SOC; Higher School of Economics Research Paper). National Research University Higher School of Economics. https://papers.ssrn.com/sol3/papers.cfm? abstract_id=2011044.

Unrath, S. (2007). Die Bedeutung des Geldes bei der Entstehung und Behandlung von Glücksspielsucht. [Thesis]. Evangelische Fachhochschule Reutlingen-Ludwigsburg.

Vaughan, G., \& Hogg, M. A. (2005). Introduction to social psychology, 4th ed.. Prentice-Hall.

Yamauchi, K. T., \& Templer, D. J. (1982). The development of a money attitude scale. Journal of Personality Assessment, 46(5), 522-528. https://doi.org/10.1207/s15327752jpa4605_ 14.

\section{APPENDIX 1}

The base set of items with their German translations, factor loadings and psychometric characteristics.

\begin{tabular}{|c|c|c|c|c|c|c|c|c|c|c|c|}
\hline \multirow[b]{2}{*}{ No. } & \multirow{2}{*}{$\begin{array}{l}\text { No. } \\
\text { SMAG }\end{array}$} & \multirow[b]{2}{*}{ Items in German } & \multirow[b]{2}{*}{ Original } & \multirow{2}{*}{$\begin{array}{l}\text { Scale/ } \\
\text { Item no. }\end{array}$} & \multicolumn{4}{|c|}{$\begin{array}{l}\text { Item characteristics } \\
\qquad(n=2,588)^{2}\end{array}$} & \multicolumn{3}{|c|}{$\begin{array}{l}\text { Factor loadings } \\
(n=1,294)^{3}\end{array}$} \\
\hline & & & & & $M^{1}$ & Miss. & $S D$ & Diff. & 1 & 2 & 3 \\
\hline 1 & & $\begin{array}{l}\text { Geld zeigt, was man } \\
\text { erreicht hat. }\end{array}$ & $\begin{array}{l}\text { Money represents one's } \\
\text { achievement. }\end{array}$ & MES $5^{\star}$ & 5.38 & 73 & 2.61 & .49 & .68 & .07 & -.01 \\
\hline 2 & 2 & Ich schätze Geld sehr. & I value money very high. & $\operatorname{MES} 46^{*}$ & 5.91 & 146 & 2.29 & .55 & .71 & .12 & -.06 \\
\hline 3 & & Geld heißt Macht. & Money means power. & MES 30 & 6.76 & 54 & 2.46 & .64 & .42 & -.05 & .00 \\
\hline 4 & 4 & $\begin{array}{l}\text { Meinen Umgang mit Geld } \\
\text { finde ich teilweise } \\
\text { beunruhigend. }\end{array}$ & $\begin{array}{l}\text { I show some worrisome } \\
\text { behavior when it } \\
\text { comes to money. }^{\text {a }}\end{array}$ & MAS 15 & 3.52 & 65 & 2.41 & .28 & -.18 & .55 & -.15 \\
\hline 5 & & $\begin{array}{l}\text { Ich beschäftige mich gern } \\
\text { und viel mit } \\
\text { Finanzthemen } \\
\text { (Börsenkurse } \\
\text { beobachten, } \\
\text { Finanzmagazine lesen, } \\
\text { etc.). }\end{array}$ & $\begin{array}{l}\text { Constructed based on two } \\
\text { items: Money will help } \\
\text { you express your } \\
\text { competence and } \\
\text { abilities (MES 25); I } \\
\text { have explicit plans for } \\
\text { how I can make more } \\
\text { money (MIS 10). }\end{array}$ & MES $25^{\star}$ & 3.67 & 49 & 2.79 & .30 & .31 & .09 & .02 \\
\hline 6 & & $\begin{array}{l}\text { Geld kann dir Luxus } \\
\text { kaufen. }\end{array}$ & $\begin{array}{l}\text { Money can buy you } \\
\text { luxuries. }\end{array}$ & MES 27 & 8.09 & 52 & 1.90 & .79 & .40 & .04 & -.17 \\
\hline 7 & 7 & Geld ist unanständig. & Money is shameful. ${ }^{a}$ & MES 32 & 3.71 & 158 & 2.39 & .30 & -.11 & -.18 & .50 \\
\hline 8 & & $\begin{array}{l}\text { Ausgegebenes Geld ist } \\
\text { verlorenes/ } \\
\text { verschwendetes Geld. }\end{array}$ & $\begin{array}{l}\text { Money spent is money } \\
\text { lost (wasted). }\end{array}$ & MES 21 & 3.14 & 71 & 1.99 & .24 & .14 & .10 & .49 \\
\hline 9 & & $\begin{array}{l}\text { Lieber risikiere ich einen } \\
\text { großen Verlust, um die } \\
\text { Chance auf einen } \\
\text { großen Gewinn zu } \\
\text { haben. }\end{array}$ & $\begin{array}{l}\text { I would prefer to win big } \\
\text { or lose big than to be } \\
\text { conservative. }^{\text {a }}\end{array}$ & MIS 21 & 2.63 & 62 & 1.80 & .18 & .24 & -.28 & .06 \\
\hline 10 & & $\begin{array}{l}\text { Ich mag es nicht, mir Geld } \\
\text { zu leihen. }\end{array}$ & $\begin{array}{l}\text { I am comfortable } \\
\text { borrowing substantial } \\
\text { sums of money for } \\
\text { investment purposes. }^{\text {b }}\end{array}$ & MIS 22 & 8.16 & 52 & 2.35 & .80 & .09 & .22 & .07 \\
\hline
\end{tabular}




\begin{tabular}{|c|c|c|c|c|c|c|c|c|c|c|c|}
\hline \multirow[b]{2}{*}{ No. } & \multirow{2}{*}{$\begin{array}{l}\text { No. } \\
\text { SMAG }\end{array}$} & \multirow[b]{2}{*}{ Items in German } & \multirow[b]{2}{*}{ Original } & \multirow{2}{*}{$\begin{array}{l}\text { Scale/ } \\
\text { Item no. }\end{array}$} & \multicolumn{4}{|c|}{$\begin{array}{l}\text { Item characteristics } \\
\qquad(n=2,588)^{2}\end{array}$} & \multicolumn{3}{|c|}{$\begin{array}{l}\text { Factor loadings } \\
(n=1,294)^{3}\end{array}$} \\
\hline & & & & & $M^{1}$ & Miss. & $S D$ & Diff. & 1 & 2 & 3 \\
\hline 11 & 11 & $\begin{array}{l}\text { Geld ist das wichtigste } \\
\text { Ziel in meinem Leben. }\end{array}$ & $\begin{array}{l}\text { Money is the most } \\
\text { important thing (goal) } \\
\text { in my life. }\end{array}$ & MES 9 & 3.51 & 58 & 2.33 & .28 & .66 & .00 & .12 \\
\hline 12 & & $\begin{array}{l}\text { Geld gibt Unabängigkeit } \\
\text { und Freiheit. }\end{array}$ & $\begin{array}{l}\text { Money gives you } \\
\text { autonomy und } \\
\text { freedom. }\end{array}$ & MES $11^{\star}$ & 7.20 & 46 & 2.06 & .69 & .54 & .10 & -.16 \\
\hline 13 & & $\begin{array}{l}\text { Geld führt dazu, dass man } \\
\text { respektiert wird. }\end{array}$ & $\begin{array}{l}\text { Money makes people } \\
\text { respect you in the } \\
\text { community. }\end{array}$ & MES $20^{*}$ & 4.89 & 86 & 2.39 & .43 & .50 & -.10 & .03 \\
\hline 14 & 12 & $\begin{array}{l}\text { Geld gibt dir die } \\
\text { Möglichkeit zu sein, } \\
\text { wer du sein willst. }\end{array}$ & $\begin{array}{l}\text { Money can give you the } \\
\text { opportunity to be } \\
\text { what you want to be. }\end{array}$ & MES 29* & 4.91 & 72 & 2.53 & .43 & .59 & -.06 & .02 \\
\hline 15 & & $\begin{array}{c}\text { Geld führt häufig zu } \\
\text { Konflikten. }\end{array}$ & $\begin{array}{l}\text { I often argue with my } \\
\text { partner (spouse, lover, } \\
\text { etc.) about money. }{ }^{c}\end{array}$ & MBBS 49 & 7.32 & 71 & 2.13 & .70 & -.09 & -.02 & .26 \\
\hline 16 & & $\begin{array}{l}\text { Ein gesparter Pfennig ist } \\
\text { zweimal verdient. }\end{array}$ & $\begin{array}{l}\text { A penny saved is a penny } \\
\text { earned. }\end{array}$ & MES 37 & 5.34 & 229 & 2.35 & .48 & .12 & .27 & .45 \\
\hline 17 & 1 & $\begin{array}{l}\text { Ich weiß jederzeit } \\
\text { ziemlich gut, wie viel } \\
\text { Geld ich besitze. }\end{array}$ & $\begin{array}{l}\text { I know almost to the } \\
\text { penny how much } \\
\text { money I have in my } \\
\text { purse, wallet or pocket } \\
\text { at all times. }{ }^{\text {c }}\end{array}$ & MBBS 8 & 8.02 & 24 & 2.16 & .78 & .11 & .53 & -.05 \\
\hline 18 & & $\begin{array}{l}\text { Ich kaufe oft Sachen, die } \\
\text { ich nicht brauche oder } \\
\text { will, nur weil sie } \\
\text { reduziert sind }\end{array}$ & $\begin{array}{l}\text { I often buy things that I } \\
\text { don't need or want } \\
\text { because they are in a } \\
\text { sale or reduced in a sale } \\
\text { or reduced in price. }\end{array}$ & MBBS 1 & 2.89 & 28 & 2.14 & .21 & .19 & -.33 & .22 \\
\hline 19 & & $\begin{array}{l}\text { Ich zahle Rechnungen } \\
\text { sofort, um Zinsen oder } \\
\text { Strafen zu vermeiden. }\end{array}$ & $\begin{array}{l}\text { I pay my bills } \\
\text { immediately in order to } \\
\text { avoid interest or } \\
\text { penalties. }\end{array}$ & MES 43 & 8.15 & 55 & 2.29 & .79 & .01 & .47 & -.04 \\
\hline 20 & 8 & $\begin{array}{l}\text { Je mehr Geld man hat, } \\
\text { desto glücklicher ist } \\
\text { man. }\end{array}$ & $\begin{array}{l}\text { I believe the more money } \\
\text { you have, the happier } \\
\text { you are. }\end{array}$ & MIS 1 & 4.02 & 105 & 2.47 & .34 & .68 & -.06 & .08 \\
\hline 21 & & $\begin{array}{l}\text { Ich fantasiere oft über Geld } \\
\text { und was ich damit tun } \\
\text { könnte. }\end{array}$ & $\begin{array}{l}\text { I often fantasize about } \\
\text { money and what I } \\
\text { could do with it. }\end{array}$ & MBBS 57 & 6.17 & 62 & 2.68 & .57 & .50 & -.07 & .14 \\
\hline 22 & 5 & $\begin{array}{l}\text { Wenn ich Geld übrig } \\
\text { habe, muss ich es } \\
\text { ausgeben. }\end{array}$ & $\begin{array}{l}\text { If I have money left over } \\
\text { at the end of the } \\
\text { month (week) I often } \\
\text { feel uncomfortable } \\
\text { until it is all spent. }\end{array}$ & MBBS 15 & 2.91 & 33 & 2.12 & .21 & -.18 & .60 & -.09 \\
\hline 23 & & $\begin{array}{l}\text { Ich weiß meistens sehr } \\
\text { genau, wie viel Geld ich } \\
\text { dabei habe. }\end{array}$ & $\begin{array}{l}\text { I know almost to the } \\
\text { penny how much } \\
\text { money I have in my } \\
\text { purse, wallet or pocket } \\
\text { at all times. }\end{array}$ & MBBS 8 & 7.87 & 28 & 2.09 & .76 & .15 & .42 & .00 \\
\hline 24 & & $\begin{array}{l}\text { Ich streite mich häufig } \\
\text { über Geld. }\end{array}$ & $\begin{array}{l}\text { I often argue with my } \\
\text { partner (spouse, lover, } \\
\text { etc.) about money. }{ }^{c}\end{array}$ & MBBS 49 & 2.20 & 30 & 1.61 & .13 & .26 & -.25 & .34 \\
\hline 25 & & $\begin{array}{l}\text { Ich würde praktisch alles } \\
\text { für Geld tun. }\end{array}$ & $\begin{array}{l}\text { I would do practically } \\
\text { anything legal for } \\
\text { money if it were } \\
\text { enough. }\end{array}$ & MBBS 43 & 2.32 & 18 & 1.86 & .15 & .47 & -.20 & .18 \\
\hline
\end{tabular}




\begin{tabular}{|c|c|c|c|c|c|c|c|c|c|c|c|}
\hline \multirow[b]{2}{*}{ No. } & \multirow{2}{*}{$\begin{array}{l}\text { No. } \\
\text { SMAG }\end{array}$} & \multirow[b]{2}{*}{ Items in German } & \multirow[b]{2}{*}{ Original } & \multirow{2}{*}{$\begin{array}{c}\text { Scale/ } \\
\text { Item no. }\end{array}$} & \multicolumn{4}{|c|}{$\begin{array}{l}\text { Item characteristics } \\
\quad(n=2,588)^{2}\end{array}$} & \multicolumn{3}{|c|}{$\begin{array}{l}\text { Factor loadings } \\
(n=1,294)^{3}\end{array}$} \\
\hline & & & & & $M^{1}$ & Miss. & $S D$ & Diff. & 1 & 2 & 3 \\
\hline 26 & & $\begin{array}{l}\text { Für Geld muss man hart } \\
\text { arbeiten. }\end{array}$ & & new $^{e}$ & 7.33 & 62 & 2.14 & .70 & .20 & .25 & .14 \\
\hline 27 & & Geld gibt Sicherheit. & $\begin{array}{l}\text { Money in the bank is a } \\
\text { sign of security. }\end{array}$ & MES 7 & 7.96 & 39 & 1.72 & .77 & .49 & .20 & -.12 \\
\hline 28 & & $\begin{array}{l}\text { Geld ist ein wichtiger } \\
\text { Faktor im Leben. }\end{array}$ & $\begin{array}{l}\text { Money is an important } \\
\text { factor in the lives of all } \\
\text { of us. }\end{array}$ & MES $1^{*}$ & 6.97 & 86 & 2.02 & .66 & .66 & .12 & -.07 \\
\hline 29 & 6 & $\begin{array}{l}\text { Ich gehe mit meinem } \\
\text { Geld sehr vorsichtig } \\
\text { um. }\end{array}$ & $\begin{array}{l}\text { I use my money very } \\
\text { carefully. }\end{array}$ & $\operatorname{MES} 47^{\star}$ & 6.69 & 78 & 2.26 & .63 & .00 & .74 & .21 \\
\hline 30 & & $\begin{array}{l}\text { Mit Geld kann man alles } \\
\text { kaufen. }\end{array}$ & $\begin{array}{l}\text { Money can buy } \\
\text { everything. }\end{array}$ & MES 3 & 4.09 & 30 & 2.89 & .34 & .49 & -.08 & .06 \\
\hline 31 & & $\begin{array}{l}\text { Auch wenn ich genug Geld } \\
\text { habe, fällt es mir schwer, } \\
\text { es für Dinge } \\
\text { auszugeben, die ich } \\
\text { brauche. }\end{array}$ & $\begin{array}{l}\text { Even when I have } \\
\text { sufficient money I often } \\
\text { feel guilty about } \\
\text { spending money on } \\
\text { necessities like clothes } \\
\text { etc. }^{\text {a }}\end{array}$ & MBBS 4 & 4.11 & 67 & 2.51 & .35 & .09 & .16 & .42 \\
\hline 32 & & $\begin{array}{l}\text { Es ist wichtig, Geld zu } \\
\text { sparen. }\end{array}$ & $\begin{array}{l}\text { I think that it is very } \\
\text { important to save some } \\
\text { money. }\end{array}$ & MES 45 & 7.54 & 51 & 1.87 & .73 & .21 & .49 & .26 \\
\hline 33 & & $\begin{array}{l}\text { Ich denke viel mehr über } \\
\text { Geld nach als die } \\
\text { meisten anderen. }\end{array}$ & $\begin{array}{l}\text { Compared to most other } \\
\text { people that I know, I } \\
\text { believe that I think about } \\
\text { money much more than } \\
\text { they do. }\end{array}$ & MBBS 55 & 4.27 & 139 & 2.48 & .36 & .49 & .15 & .30 \\
\hline 34 & 10 & $\begin{array}{l}\text { Geld ist das Symbol für } \\
\text { Erfolg. }\end{array}$ & $\begin{array}{l}\text { Money is a symbol of } \\
\text { success. }\end{array}$ & MES $8^{*}$ & 5.51 & 74 & 2.47 & .50 & .74 & .06 & -.01 \\
\hline 35 & & $\begin{array}{l}\text { Geld kann dir viele } \\
\text { Freunde schaffen. }\end{array}$ & $\begin{array}{l}\text { Money can bring you } \\
\text { many friends. }\end{array}$ & MES 12 & 3.12 & 44 & 2.37 & .24 & .30 & -.11 & .13 \\
\hline 36 & & $\begin{array}{l}\text { Ich gebe Geld aus, um } \\
\text { mich besser zu fühlen. }\end{array}$ & $\begin{array}{l}\text { I spend money to make } \\
\text { myself feel better. }\end{array}$ & MAS 19 & 3.53 & 53 & 2.39 & .28 & .30 & -.42 & .06 \\
\hline 37 & 3 & $\begin{array}{l}\text { Geld ist die Wurzel allen } \\
\text { Übels. }\end{array}$ & $\begin{array}{l}\text { Money is the root of all } \\
\text { evil. } f\end{array}$ & $\underset{f}{\text { MES-S }} 12$ & 4.93 & 126 & 2.72 & .44 & -.10 & -.11 & .44 \\
\hline 38 & 9 & $\begin{array}{l}\text { Ich teile mir mein Geld } \\
\text { sehr gut ein. }\end{array}$ & $\begin{array}{l}\text { I budget my money very } \\
\text { well. }\end{array}$ & $\operatorname{MES} 48^{*}$ & 6.85 & 91 & 2.27 & .65 & .01 & .76 & .06 \\
\hline
\end{tabular}

Note: No. SMAG - Item number in the final version of the scale; MES - Money Ethic Scale ( ${ }^{*}$ short version); MAS - Money Attitude Scale; MBBS - Money Belief and Behavior Scale; MIS - Money Importance Scale; Miss. - missing values, $M$ - mean, $S D$ - standard deviation, Diff. - item difficulty; Items included in the final scale are written in bold; ${ }^{a}$ phrasing adjusted; ${ }^{\mathrm{b}}$ positive phrasing changed to negative; ${ }^{\mathrm{c}}$ original item divided into two items in the German version (item no.: 15 and 24,17 and 23); ${ }^{\mathrm{e}}$ new item; ${ }^{\mathrm{f}}$ the original MES-15 item 'money is evil' could not be translated and was replaced by the MES-Short item no. 12; ${ }^{1}$ all items had a range between 1 and $10{ }^{2}$ pairwise deletion when missing values; ${ }^{3}$ listwise deletion when missing values, the German factor names are: Geld als Erfolgssymbol, Haushalten mit Geld and Übel/Böse. 


\section{APPENDIX 2}

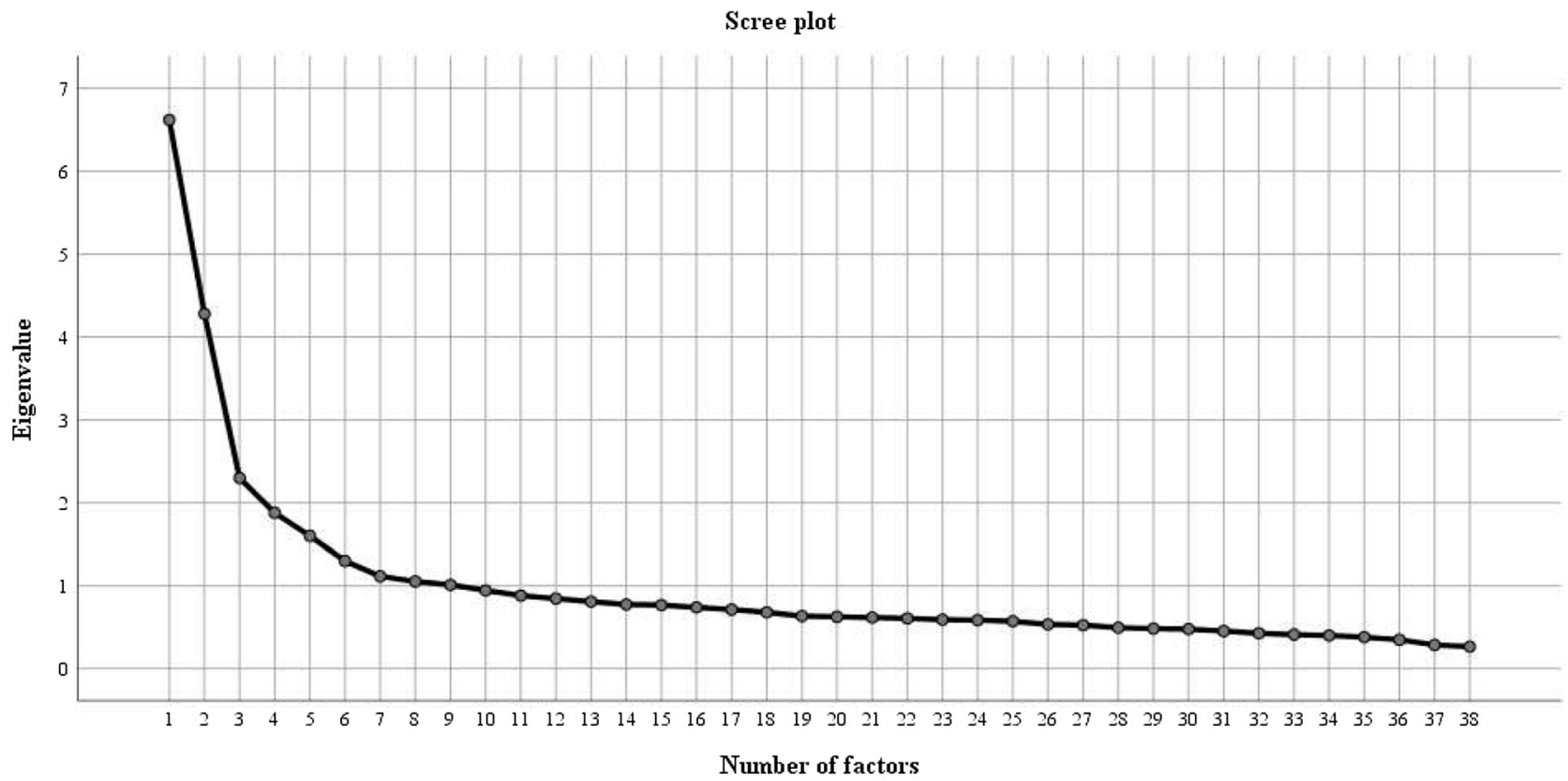

Scree plot of the Eigenvalues in the exploratory factor analysis. The three-factor solution was chosen based on the scree plot and a theoretical consideration: The excluded factors (4-9) were either strongly under-determined with no or only one item excluding factor loading of 0.3 (factors $5,7,8,9$ ), included heterogeneous items (factor 4) or were very similar to the obtained factors (factors 6 similar to the Budget-factor) 